\title{
Perbedaan air rebusan daun seledri dan air rebusan daun salam terhadap penurunan tekanan darah pada pra lansia dengan hipertensi primer
}

\author{
Asep Badrujamaludin ${ }^{1 *}$, Budiman², Tifany Desty Erisandi \\ 1Program Studi Keperawatan (D3), STIKES Jenderal Achmad Yani- Cimahi. *Email: dru.stikesr@gmail.com \\ 2Program Studi IImu Kesehatan Masyarakat (S1), STIKES Jenderal Achmad Yani- Cimahi \\ 3Program Studi IImu Keperawatan S1, STIKES Jenderal Achmad Yani- Cimahi
}

\begin{abstract}
The effect of celery (apium graveolens) leaf and bay leaf (Syzygium polyanthum wight) on the blood pressure in pre-elderly with primary hypertension
\end{abstract}

Background: Hypertension, also known as high blood pressure, is as medical condition in which the blood pressure in arteries is persistently elevated. This condition can increase risk of cardiovascular diseases such as stroke, kidney failure, heart attack, and kidney damage. Hypertension requires proper treatment to prevent uncontrolled blood pressure that can cause damaged organs. One of traditional treatment for hypertension is using celery leaves (Apium graveolens $L$ ) and bay leaves (Syzygium polyantum).

Purpose: This research is to determine the difference of blood pressure after the consumption of boiled water celery leaves and bay leaves in pre-elderly with hypertension at Cigugur Tengah Public Health Center.

Method: The type of this research is the numerical comparative analytic with Quasi Experiment design with Non Equivalent Control Group Design. This research used purposive sampling technique using 22 responden with inclusion and exclusion criteria. Data collection was performed by measuring the blood pressure before and after the consumption of celery leaves and bay leaves boiled water that consume twice a day in one week. The data are processed including univariate and bivariate data analysis.

Results: The statistical result of T-independent test obtain $p$ value of $0,365>a(0,05)$ for the systolic blood pressure and $0,574>a(0,05)$ for diastolic blood pressure.

Conclusion: Result showed that there is no average difference of blood pressure in group intervention boiled water of celery leaves and bay leaves after consumption of boiled water celery leaves and bay leaves. However, both intervention have decreased blood pressure of hypertension patient.Suggestion of this research is to consume boiled water of celery leaves and bay leaves for longer time as additional therapy for hypertension patient.

\section{Keywords: Pre-elderly; Celery leaf; Bay leaf; Primary hypertension}

Pendahuluan: Hipertensi merupakan suatu keadaan tekanan darah yang tinggi di dalam arteri, sehingga meningkatkan risiko terhadap penyakit-penyakit yang berhubungan dengan kardiovaskuler seperti stroke, gagal ginjal, serangan jantung, dan kerusakan ginjal. Hipertensi membutuhkan penanganan yang tepat untuk mencegah tidak terkontrolnya tekanan darah yang dapat menyebabkan organ tubuh menjadi rusak. Salah satu pengobatan alami hipertensi yang dilakukan adalah pengobatan dengan menggunakan daun seledri (Apium graveolens $L$ ) dan daun salam (Syzygium polyanthum).

Tujuan: Untuk mengetahui perbedaan tekanan darah sesudah pemberian air rebusan daun seledri dan air rebusan daun salam terhadap penurun tekanan darah pada pra lansia dengan hipertensi primer

Metode: Analitik komparatif numerik tidak berpasangan dengan desain Quasi Eksperimen dengan rancangan Non Equivalent Control Group. Pengambilan sampel dilakukan secara teknik purposive sampling sebanyak 22 responden. Pengumpulan data dilakukan dengan cara mengukur tekanan darah responden sebelum dan sesudah diberikan perlakuan dua kali sehari selama satu minggu. Pengolahan dengan menggunkan uji $T$ independent diperoleh nilai $p$ value tekanan darah sistolik $0,365>a(0,05)$ dan $p$ value tekanan darah diastolik $0,574>a(0,05)$. 
Perbedaan air rebusan daun seledri dan air rebusan daun salam terhadap penurunan tekanan darah pada pra lansia dengan hipertensi primer

Hasil: Tidak terdapat perbedaan yang signifikan rerata tekanan darah pada kelompok intervensi baik yang diberikan air rebusan daun seledri dan air rebusan daun salam.

Simpulan: Terdapat penurunan tekanan darah dari kedua kelompok intervensi tersebut bagi penderita hipertensi. Saran dari penelitian ini diharapkan penderita yang mengalami hipertensi dapat mengaplikasikan air rebusan daun seledri dan air rebusan daun salam dalam kurun waktu lama sebagai tambahan terapi untuk hipertensi.

\section{Kata Kunci: Air rebusan; Daun seledri; Daun salam; Tekanan darah; Pra lansia; Hipertensi primer}

\section{PENDAHULUAN}

Pada tahun 2016 di Jawa Barat ditemukan 790.382 orang kasus hipertensi. Menurut jumlah penduduk berusia $\geq 18$ tahun terdapat $2,46 \%$ kasus hipertensi, tersebar di 26 Kabupaten/Kota, penemuan kasus tertinggi di Cirebon (17,18\%) dan terendah di Kabupaten Pangandaran (0,05\%). Angka kejadian hipertensi cenderung lebih tinggi pada perempuan dibandingkan pada laki-laki (Dinas Kesehatan Provinsi Jawa Barat, 2016). Data terbaru dari Dinas Kesehatan Kota Cimahi tahun 2018, ditemukan kasus hipertensi sebanyak 47.200 orang. Kecamatan dengan kasus tertinggi yaitu Cimahi Selatan sebanyak 4552 orang dan disusul oleh Cipageran sebanyak 4948 orang dan Cimahi Utara sebanyak 4522 orang, sedangkan terendah di Melong Tengah sebanyak 1406 orang. Menurut laporan morbidibitas pra lansia dengan rentang usia 45-59 yang mengalami hipertensi tertinggi di Cibereum sebanyak 219 orang, Cigugur Tengah sebanyak 163 orang dan Cimahi Utara sebanyak 124 orang (Dinas Kesehatan Kota Cimahi, 2018). Hipertensi membutuhkan penanganan yang tepat untuk mencegah tidak terkontrolnya tekanan darah yang dapat menyebabkan organ tubuh menjadi rusak. Penanganan hipertensi dapat dilakukan dengan farmakologi yang menggunakan obat obatan yang perlu di konsumsi seumur hidup dan nonfarmakologis tanpa obat-obatan tetapi dengan memberikan terapi olah raga, pengaturan diet, merubah gaya hidup dan pengaturan berat badan. Adapun terapi komplementernya yaitu terapi herbal seperti terapi rebusan daun seledri, bawang putih, daun salam, daun alpukat dan mengkudu (Junaedi, Yulianti \& Rinata, 2013).

Pada saat ini masyarakat mencoba menggunakan bahan alami sebagai pengobatan alternatif yang dianggap lebih aman jika dibandingkan dengan obat-obatan kimia. Pengobatan tradisional menjadi alternatif karena tidak menimbulkan efek samping yang berbahaya karena menggunakan bahan alami dari tumbuh. Bahan alami yang dapat dikomsumsi untuk pengobatan hipertensi adalah dengan daun seledri (Apium graveolens $L$ ) dan daun salam (Syzygium polyanthum). Hasil penelitian yang telah dilakukan oleh Muzakar (2012) pada penderita hipertensi di wilayah kerja Puskesmas Kenten Laut dengan judul pengaruh pemberian air rebusan seledri terhadap penurunan tekanan darah diambil kesimpulan sebagai berikut : Rata-rata penurunan tekanan darah sistolik setelah diberikan air rebusan seledri adalah $20,32 \mathrm{mmHg}$ dan rata-rata penurunan tekanan darah diastolik setelah diberikan air rebusan seledri adalah 7,09 $\mathrm{mmHg}$.

Disamping seledri, daun salam (Syzygium polyanthum) juga dimungkinkan dapat digunakan untuk pengobatan alternatif yang berkhasiat sebagai obat untuk menurunkan tekanan darah. Tanaman ini terbukti efektif dalam menyembuhkan penyakit, efek samping minimal, serta mudah diperoleh. Daun salam memiliki kandungan minyak atsiri, sitrat, eugenol, tannin, flavonoid. Kandungan senyawa aktif daun salam yang bermanfaat untuk kesehatan yaitu senyawa antioksidan dalam hubungannya dengan tekanan darah yang terdiri dari tannin dan flavonoid (Herliana, 2013).

Berdasarkan data Dinas Kesehatan Kota Cimahi Desember tahun 2018 bahwa Puskesmas Cigugur Tengah merupakan puskesmas kedua yang memiliki pasien pra lansia hipertensi terbanyak di Kota Cimahi sebanyak 163 kasus. Selain itu, dari data Puskesmas Cigugur Tengah Desember tahun 2018, penderita hipertensi usia $>30$ tahun sebanyak 152 orang. Dari 10 penyakit terbanyak yang ada disana, hipertensi merupakan penyakit terbanyak urutan ke-4.

Berdasarkan fenomena tersebut, maka peneliti tertarik untuk meneliti tentang perbedaan pemberian air rebusan daun seledri dan air rebusan daun salam terhadap hipertensi primer

\footnotetext{
Asep Badrujamaludin", Budiman ${ }^{2}$, Tifany Desty Erisandi ${ }^{3}$

'Program Studi Keperawatan (D3), STIKES Jenderal Achmad Yani- Cimahi. *Email: dru.stikesr@gmail.com

${ }^{2}$ Program Studi llmu Kesehatan Masyarakat (SI), STIKES Jenderal Achmad Yani- Cimahi

${ }^{3}$ Program Studi llmu Keperawatan SI, STIKES Jenderal Achmad Yani- Cimahi
} 
Perbedaan air rebusan daun seledri dan air rebusan daun salam terhadap penurunan tekanan darah pada pra lansia dengan hipertensi primer

sebagai terapi alternatif atau terapi non farmakologis untuk menurunkan tekanan darah.

\section{METODE PENELITIAN}

Jenis penelitian quasi eksperimen dengan rancangan Non Equivalent Control Group dengan membandingkan hasil intervensi kelompok intervensi 1 dan kelompok intervensi 2 yang dilakukan dengan cara non random. Kemudian dilakukan pre test pada kelompok yang mengkonsumsi air rebusan daun seledri dan air rebusan daun salam. Setelah beberapa waktu akan dilakukan post test pada kedua kelompok tersebut.

Populasinya seluruh pra lansia yang menderita hipertensi di Wilayah Kerja Puskesmas Cigugur Tengah sebanyak 163 responden. Sampel penelitian ini adalah pra lansia usia 45-59 tahun dengan berat badan normal, yang menderita hipertensi di Wilayah Kerja Puskesmas Cigugur Tengah. Maka sampel yang diperlukan keseluruhan dalam penelitian ini 22 responden, dimana untuk kelompok intervensi 1 pemberian air rebusan daun salam sebanyak 11 orang pra lansia dan untuk kelompok intervensi 2 pemberian air rebusan daun salam sebanyak 11 orang pra lansia dengan kriteria, mempunyai riwayat hipertensi primer, sedang menjalani pengobatan farmakologi obat antihipertensi amlodipin dengan dosis $5 \mathrm{mg}$ $1 \times 1$ hari pada malam hari, tidak menjalani terapi komplementer lainnya seperti senam yoga, relaksasi progresif dan lain-lain, tidak merokok 1 tahun kebelakang, tidak mengkonsumsi alkohol.

Penelitian ini mendapat Persetujuan etik dari komisi etik penelitian kesehatan STIKES Jend. A Yani Cimahi, nomor: 05/KEPK/V/2019 dan Surat ljin penelitian dari Dinas Kesehatan Kota Cimahi, Jawa barat dengan Nomor: 070/1425/ Dinkes.

Cara pembuatan air rebusan daun seledri dengan 40 gram daun seledri dengan air $400 \mathrm{ml}$, kemudian direbus 15 menit hingga menjadi $200 \mathrm{ml}$, kemudian air di saring dan menjadi hangat di berikan minum 2 kali sehari pagi dan sore hari dan di berikan selama 1 minggu.

Adapun pembuatan air rebusan salam, dari 7 lembar daun salam dengan $750 \mathrm{cc}$, direbus hingga mendidih dan tersisa 1 gelas, $250 \mathrm{cc}$, kemudian disaring dan dinginkan dan di berikan 2 kali sehari, pagi dan sore selama 1 minggu.

Selama penelitian ini, tidak ada keluhan yang serius dari responden terkait dengan pemakaian rebusan itu baik daun salam atau seledri seperti pusing. Adapaun yang disampaikan dari responden rebusan daun seledri dimana pasien mengalami buang air kecil lebih sering dari sebelumnya. Efek samping ini juga sesuai dengan penelitian dan teori terkait dengan akan mengalami kencing agak sering dan juga disampikan kepada responden, tapi tidak mengganggu terkait pola tidur pasien. Adapun terkait dengan pemberian air rebusan daun salam tidak ada keluhan terkait buang air kecil sering.

\footnotetext{
Asep Badrujamaludin ${ }^{1 *}$, Budiman ${ }^{2}$, Tifany Desty Erisandi ${ }^{3}$

'Program Studi Keperawatan (D3), STIKES Jenderal Achmad Yani- Cimahi. *Email: dru.stikesr@gmail.com

${ }^{2}$ Program Studi llmu Kesehatan Masyarakat (SI), STIKES Jenderal Achmad Yani- Cimahi

${ }^{3}$ Program Studi llmu Keperawatan SI, STIKES Jenderal Achmad Yani- Cimahi
} 
Perbedaan air rebusan daun seledri dan air rebusan daun salam terhadap penurunan tekanan darah pada pra lansia dengan hipertensi primer

HASIL

Tabel 1. Rerata Tekanan Darah di Dalam Kelompok Intervensi

\begin{tabular}{|c|c|c|c|c|c|}
\hline Kelompok Intervensi & & N & Mean & SD & $\begin{array}{l}\text { Minimal- } \\
\text { maksimal }\end{array}$ \\
\hline \multicolumn{6}{|l|}{$\begin{array}{l}\text { Intervensi Dengan Air } \\
\text { Rebusan Daun Seledri. }\end{array}$} \\
\hline \multirow{2}{*}{ Sebelum } & Sistolik & \multirow{2}{*}{11} & 151.18 & 5.154 & $145-160$ \\
\hline & Diastolik & & 94.82 & 4.771 & $84-100$ \\
\hline Sesudah & $\begin{array}{l}\text { Sistolik } \\
\text { Diastolik }\end{array}$ & 11 & $\begin{array}{l}140.36 \\
84.82\end{array}$ & $\begin{array}{l}5.954 \\
5.056\end{array}$ & $\begin{array}{c}130-150 \\
78-94\end{array}$ \\
\hline \multicolumn{6}{|l|}{$\begin{array}{l}\text { Intervensi dengan Air } \\
\text { Rebusan Daun Salam. }\end{array}$} \\
\hline Sebelum & $\begin{array}{l}\text { Sistolik } \\
\text { Diastolik }\end{array}$ & 11 & $\begin{array}{l}151.18 \\
98.18\end{array}$ & $\begin{array}{l}7.222 \\
1.779\end{array}$ & $\begin{array}{c}140-160 \\
95-100\end{array}$ \\
\hline Sesudah & $\begin{array}{l}\text { Sistolik } \\
\text { Diastolik }\end{array}$ & 11 & $\begin{array}{l}137.27 \\
86.27\end{array}$ & $\begin{array}{l}9.318 \\
6.769\end{array}$ & $\begin{array}{c}124-152 \\
76-96\end{array}$ \\
\hline
\end{tabular}

Berdasarkan hasil penelitian dari tabel 1 rerata tekanan darah sistolik dan diastolik pada pra lansia dengan hipertensi sebelum diberikan air rebusan daun seledri adalah $151,18 \mathrm{mmHg}$ dan 94,82 $\mathrm{mmHg}$. Sedangkan rerata tekanan darah sistolik dan diastolik pada pra lansia dengan hipertensi sesudah diberikan air rebusan daun seledri adalah $140,36 \mathrm{mmHg}$ dan $84,82 \mathrm{mmHg}$. Berdasarkan hasil tersebut, maka dapat disimpulkan bahwa rerata tekanan darah pada kelompok intervensi sebelum dilakukan terapi masuk kedalam kategori hipertensi derajat 1.

Berdasarkan hasil penelitian ini, tekanan darah responden sebelum dan sesudah diberikan air rebusan daun seledri pada kelompok intervensi 1 terjadi penurunan dengan selisih tekanan darah sistolik dan diastolik adalah 10,82 $\mathrm{mmHg}$ dan 10 $\mathrm{mmHg}$. Penurunan ini dilihat berdasarkan nilai statistik bukan berdasarkan nilai klinis. Jika dilihat berdasarkan nilai klinis penurunan tekanan darah responden pada sistolik belum mencapai tekanan darah normal yaitu kurang dari $135 \mathrm{mmHg}$ dan masih dalam batas hipertensi yaitu lebih dari 140 $\mathrm{mmHg}$ sedangkan tekanan darah diastolik sudah mencapai tekanan darah normal yaitu kurang dari $85 \mathrm{mmHg}$. Sehingga terdapat selisih tekanan darah sebelum dan sesudah pada sistolik sebesar 13,91 dan diastolik 11,91.
Berdasarkan penyebabnya menurut Triyanto (2014) Hipertensi primer yaitu hipertensi yang paling banyak yaitu sekitar $90-95 \%$ akibat dari genetik dan ras termasuk faktor lain yang diantaranya adalah faktor stress, intake alkohol moderat, merokok, lingkungan, demografi dan gaya hidup sedangkan hipertensi sekunder adalah hanya sekitar $5-10 \%$ yang penyebabnya dapat diketahui, antara lain kelainan pembuluh darah ginjal, gangguan kelenjar tiroid (hipertiroid), penyakit kelenjar adrenal (hiperaldosteronisme).

Dari 11 responden yang telah diteliti, semua responden termasuk hipertensi primer. Hasil observasi kondisi hipertensi yang di alami responden disebabkan oleh faktor usia, jenis kelamin, stress dan riwayat keluarga. Faktor usia menjadi salah satu penyebabnya karena pada saat penelitian berlangsung meskipun usia sudah disamakan dalam rentang 45-59 atau pra lansia tetapi masih mengalami peningkatan tekanan darah. Hal ini dikarenakan adanya proses menua sehingga terjadinya penurunan sistem pada tubuh terutama pada sistem kardiovaskuler yaitu terjadi hipertrofi pada ventrikel kiri, kemampuan perengan jantung berkurang karena perubahan pada jaringan ikat, jantung mengalami penebalan pada katup sehingga menjadi kaku, kehilangan elastisitas pembuluh darah dan tekanan darah

Asep Badrujamaludin*, Budiman ${ }^{2}$, Tifany Desty Erisandi ${ }^{3}$

'Program Studi Keperawatan (D3), STIKES Jenderal Achmad Yani- Cimahi. *Email: dru.stikesr@gmail.com

${ }^{2}$ Program Studi llmu Kesehatan Masyarakat (SI), STIKES Jenderal Achmad Yani- Cimahi

${ }^{3}$ Program Studi llmu Keperawatan SI, STIKES Jenderal Achmad Yani- Cimahi 
Perbedaan air rebusan daun seledri dan air rebusan daun salam terhadap penurunan tekanan darah pada pra lansia dengan hipertensi primer

meningkat akibat meningkatnya resistensi pembuluh darah perifer (Balasuriya \& Rupasinghe, 2011). Peningkatan saraf simpatis dapat meningkatkan tekanan darah secara intermitten (tidak menentu). Apabila stres berkepanjangan, dapat mengakibatkan tekanan darah menetap tinggi. Hasil penelitian ini sesuai dengan penelitian yang dilakukan oleh Andria (2013) bahwa ada hubungan antara perilaku olahraga dan stress dengan tingkat hipertensi pada lanjut usia di posyandu lansia kelurahan gebang putih kecamatan sukolilo kota Surabaya. Pada penelitian ini, semuanya hipertensi primer, yang dapat dipengaruhi oleh faktor usia, stress, jenis kelamin dan riwayat keluarga. Upaya untuk meminimalkan atau mengontrol tekanan darah menggunakan pendekatan non farmakologi dengan cara antara lain dengan menggunakan terapi air rebusan daun seledri.

Berdasarkan tabel 1 didapatkan pada kelompok intervensi 2 rerata tekanan darah sebelum diberikan air rebusan daun salam tekanan darah sistolik $151,18 \mathrm{mmHg}$ dan diastolik $98,18 \mathrm{mmHg}$ dengan standar deviasi sistolik 7,222 dan diastolik 1,779. Sistolik terendah 140 dan tertinggi 160 , diastolik terendah 95 dan tertinggi 100. Rerata tekanan darah sesudah diberikan air rebusan daun salam tekanan darah sistolik $137,27 \mathrm{mmHg}$ dan diastolik $86,27 \mathrm{mmHg}$ dengan standar deviasi sistolik 9,318 dan diastolik 6,769 . Sistolik terendah 124 dan tertinggi 152, diastolik terendah 76 dan tertinggi 96. Rerata tekanan darah pada kelompok intervensi sebelum dilakukan terapi masuk kedalam kategori hipertensi normal-tinggi. Jika tekanan darah lebih dari $140 / 90 \mathrm{mmHg}$ maka dapat dinyatakan sebagai hipertensi. Adapun nilai di antaranya termasuk normal-tinggi (diperuntukkan bagi individu dewasa berusia diatas
18 tahun) (Wijayakesuma, 2015; Aspiani, 2014). Dari 12 responden yang telah diteliti, semua responden termasuk hipertensi primer. Hasil observasi kondisi hipertensi yang di alami responden disebabkan oleh faktor usia, gaya hidup, stress dan riwayat keluarga.

Faktor usia menjadi salah satu penyebabnya karena pada saat penelitian berlangsung meskipun usia sudah disamakan dalam rentang 45-59 atau pra lansia tetapi masih mengalami peningkatan tekanan darah. Hal ini dikarenakan adanya proses menua sehingga terjadinya penurunan sistem pada tubuh terutama pada sistem kardiovaskuler yaitu terjadi hipertrofi pada ventrikel kiri, kemampuan perengangan jantung berkurang karena perubahan pada jaringan ikat, jantung mengalami penebalan pada katup sehingga menjadi kaku, kehilangan elastisitas pembuluh darah dan tekanan darah meningkat akibat meningkatnya resistensi pembuluh darah perifer (Balasuriya \& Rupasinghe, 2011). Asupan harian garam orang dewasa adalah 5 sampai $15 \mathrm{~g}$, tapi efek terapi pengurangan garam pada hipertensi hendaknya mengonsumsi garam tidak lebih dari $100 \mathrm{mmol} / \mathrm{hari}$ atau 2,4 gram natrium, atau 6 gram natrium klorida ( \pm 1 sendok teh/hari). Selain itu, stres merupakan respon tubuh yang sifatnya nonspesifik terhadap tuntutan beban pikiran. Stres akan meningkatkan resistensi pembuluh darah perifer dan curah jantung sehingga akan menstimulasi aktivitas saraf simpatetis (Black \& Hawks, 2009; Morika \& Yurnike, 2016).

Saraf simpatetis akan memicu kerja jantung dan menyebabkan peningkatan tekanan darah. Hasil wawancara didapatkan 3 dari 12 responden mengeluh stress. Apabila kedua orang tua mengidap hipertensi, kemungkinan hipertensi naik menjadi $60 \%$.

\footnotetext{
Asep Badrujamaludin*, Budiman ${ }^{2}$, Tifany Desty Erisandi ${ }^{3}$

'Program Studi Keperawatan (D3), STIKES Jenderal Achmad Yani- Cimahi. *Email: dru.stikesr@gmail.com

${ }^{2}$ Program Studi llmu Kesehatan Masyarakat (SI), STIKES Jenderal Achmad Yani- Cimahi

${ }^{3}$ Program Studi llmu Keperawatan S1, STIKES Jenderal Achmad Yani- Cimahi
} 
Perbedaan air rebusan daun seledri dan air rebusan daun salam terhadap penurunan tekanan darah pada pra lansia dengan hipertensi primer

Tabel 2. Perbedaan Rerata Tekanan Darah Dari Pengaruh Intervensi

\begin{tabular}{lccccc}
\hline \multicolumn{1}{c}{ Tekanan Darah } & Mean & Median & SD & p-value & N \\
\hline $\begin{array}{l}\text { Sistolik sebelum mengonsumsi } \\
\text { air rebusan daun seledri }\end{array}$ & 151,18 & 149,00 & 5,154 & 0,001 & 11 \\
$\begin{array}{l}\text { Sistolik sesudah mengonsumsi } \\
\text { air rebusan daun seledri }\end{array}$ & 140,36 & 141,00 & 5,954 & & 11 \\
$\begin{array}{l}\text { Diastolik sebelum mengonsumsi } \\
\text { air rebusan daun seledri }\end{array}$ & 94,82 & 95,00 & 4,771 & 0,001 & 11 \\
$\begin{array}{l}\text { Diastolik sesudah mengonsumsi } \\
\text { air rebusan daun seledri }\end{array}$ & 84,53 & 84,00 & 5,056 & & \\
$\begin{array}{l}\text { Sistolik } \\
\text { sebelum mengonsumsi air } \\
\text { rebusan daun salam }\end{array}$ & 151,18 & 153,00 & 7,222 & 0,001 & 11 \\
$\begin{array}{l}\text { Sistolik } \\
\text { sesudah mengonsumsi air } \\
\text { rebusan daun salam }\end{array}$ & 137,27 & 136,00 & 9,318 & & \\
$\begin{array}{l}\text { Diastolik } \\
\text { sebelum mengonsumsi air } \\
\text { rebusan daun salam }\end{array}$ & 98,18 & 98,00 & 1,779 & 0,001 & 11 \\
$\begin{array}{l}\text { Diastolik sesudah mengonsumsi } \\
\text { air rebusan daun salam }\end{array}$ & 86,27 & 85,00 & 6,769 & & \\
\hline
\end{tabular}

Tabel 2 diatas menunjukkan bahwa rata-rata tekanan sistolik sebelum intervensi 1 adalah $151,18 \mathrm{mmHg}(\mathrm{SD}=5,154)$ dan rata-rata tekanan sistolik sesudah intervensi 1 adalah $140,36 \mathrm{mmHg}$ $(S D=5,594)$. Terlihat perbedaan rata-rata tekanan sistolik sebelum dan sesudah mengonsumsi air rebusan daun seledri sebesar $10,82 \mathrm{mmHg}$. Sedangkan rata-rata tekanan diastolik sebelum diberikan intervensi 1 adalah 94,82 $\mathrm{mmHg}(\mathrm{SD}=$ $4,771)$ dan rata-rata diastolik sesudah diberikan intervensi 1 adalah 84,82 $\mathrm{mmHg}(\mathrm{SD}=5,056)$. Terlihat adanya penurunan dari diastolik sebelum dan sesudah mengonsumsi air rebusan daun seledri sebesar $10 \mathrm{mmHg}$. Setelah dilakukan uji statistik nilai rata-rata sistolik sebelum dan sesudah intervensi 1 diperoleh $p$ value $=0,001<a$
$=0,05$. Hal ini bermakna bahwa ada pengaruh dari konsumsi air rebusan daun seledri terhadap tekanan darah sistolik pada pra lansia dengan hipertensi. Kemudian setelah dilakukan uji statistik rata-rata tekanan diastolik sebelum dan sesudah intervensi 1 diperoleh $p$ value $=0,001<a=0,05$. Hal ini bermakna bahwa ada pengaruh dari konsumsi seduhan air rebusan daun seledri terhadap tekanan darah diastolik pada pra lansia dengan hipertensi.Hasil uji statistik pada tekanan darah sistolik didapatkan $p$ value 0,001 dan uji statistik pada tekanan darah diastolik $p$ value 0,001 . Dari hasil penelitian diatas, dapat disimpulkan bahwa terdapat perbedaan atau pengaruh pada tekanan darah sistolik dan diastolik sesudah diberikan air rebusan daun seledri. Seledri memiliki efek yang baik untuk menurunkan

Asep Badrujamaludin ${ }^{1 *}$, Budiman ${ }^{2}$, Tifany Desty Erisandi ${ }^{3}$

'Program Studi Keperawatan (D3), STIKES Jenderal Achmad Yani- Cimahi. *Email: dru.stikesr@gmail.com

${ }^{2}$ Program Studi llmu Kesehatan Masyarakat (SI), STIKES Jenderal Achmad Yani- Cimahi

${ }^{3}$ Program Studi llmu Keperawatan SI, STIKES Jenderal Achmad Yani- Cimahi 
Perbedaan air rebusan daun seledri dan air rebusan daun salam terhadap penurunan tekanan darah pada pra lansia dengan hipertensi primer

tekanan darah pada penderita hipertensi. Seledri mengandung flavonoid, saponin, tanin $1 \%$, minyak atsiri 0,033\%, flavo-glukosida (apiin), apigenin, fitosterol, kolin, lipase, pthalides, asparagine, zat pahit, vitamin (A,B, dan C) (Saputra \& Fitria 2016). Dalam ilmu botani, daun seledri dikatakan memiliki kandungan apigenin yang dapat mencegah penyempitan pembuluh darah dan pthalides yang dapat mengendurkan otot-otot arteri atau merelaksasi pembuluh darah. Zat tersebut mengatur aliran darah sehingga memungkinkan pembuluh darah membesar dan mengurangi tekanan darah (Saputra \& Fitria (2016).

Kandunagn aktif antihipertensi adalah apigenin yang merupakan senyawa flavonoid dengan gugus hidroksi bebas dengan nomor atom karbon 4,8 dan 5,7 . Apigenin yang berfungsi sebagai beta blocker pada daun seledri yang dapat memperlambat detak jantung dan menurunkan kekuatan kontraksi jantung sehingga aliran darah yang terpompa lebih sedikt dan tekanan darah menjadi berkurang. Selain itu, vasodilator (melebarkan pembuluh darah) adalah salah satu sifat dari apigenin dengan mekanisme pelepasan kalsium (mekanisme kerja seperti kalsium antagonis) yang akan menghambat kontraksi yang disebabkan oleh Antagonis kalsium yang akan menurunkan tekanan darah dengan cara pembuluh darah akan melebar sehingga darah mengalir dengan lancar (Palmer, 2007; Saputra \& Fitria, 2016 ).

Peningkatkan Cairan intraseluler dengan menarik cairan ekstraseluler juga merupakan hasil dari potasium (kalium) yang terdapat dalam kandungan seledri yang akan merubah keseimbahan pompa natrium-kalium yang mengakibatkan penurunan tekanan darah. Selain itu, perubahan keseimbangan $\mathrm{Na}+$ juga merupakan cara untuk penanganan hipertensi dengan salah satunya pemberian diuretik oral (Saputra \& Fitria, 2016).

Menunjukkan bahwa rata-rata tekanan sistolik sebelum diberikan intervensi 2 adalah 151,18 $\mathrm{mmHg}(\mathrm{SD}=7,222)$ dan rata-rata sistolik sesudah diberikan intervensi 2 adalah 137,27 (SD = 9,318). Terlihat perbedaan rata-rata antara tekanan sistolik sebelum dan sesudah diberikan air rebusan daun salam sebesar $13,91 \mathrm{mmHg}$. Sedangkan rata-rata tekanan diastolik sebelum diberikan intervensi 2 adalah $98,18 \mathrm{mmHg}(\mathrm{SD}=1,779)$ dan rata-rata tekanan diastolik sesudah diberikan intervensi 2 adalah $86,27 \mathrm{mmHg}(\mathrm{SD}=6,769)$. Terlihat adanya perbedaan rata-rata antara tekanan diastolik sebelum dan sesudah diberikan air rebusan daun salam sebesar $11,91 \mathrm{mmHg}$.

Setelah dilakukan uji statistik nilai tengah tekanan sistolik sebelum dan sesudah intervensi 2 diperoleh $p$ value $=0,001<a=0,05$. Hal ini bermakna bahwa ada pengaruh dari konsumsi air rebusan daun salam terhadap tekanan darah pada pra lansia dengan hipertensi.Kemudian setelah dilakukan uji statistik nilai tengah tekanan diastolik sebelum dan sesudah intervensi 2 diperoleh $p$ value $=0,001<a=0,05$. Hal ini bermakna bahwa terdapat pengaruh dari konsumsi air rebusan daun salam terhadap tekanan darah diastolik pada pra lansia dengan hipertensi.

Daun salam merupakan salah satu jenis tanaman yang dapat digunakan sebagai terapi herbal untuk menangani hipertensi. Kandungan kimia dalam daun salam yang mempunyai fungsi menurunkan tekanan darah yaitu minyak atsiri (sitrat, eugenol), tannin dan flavanoid (Putri, 2015). Kandungan kimia dalam daun salam yang diduga berperan terhadap penurunan tekanan darah adalah flavonoid. Senyawa ini dapat menurunkan systemic vascular resitance (SVR) karena menyebabkan vasodilatasi dan mempengaruhi kerja angiotensi converting enzyme (ACE) yang mampu menghambat terjadinya perubahan angiotensi I menjadi angiotensi II. Efek vasodilatasi dan inhibitor ACE dapat menurunkan tekanan darah (Junaedi, Yulianti, \& Rinata, 2013).

Menurut Widiasari (2018) flavonoid adalah kelompok senyawa alam dengan variabel struktur fenolik dan dapat ditemukan pada tumbuhan. Flavonoid dapat dibagi menjadi berbagai macam kelompok seperti flavons (contohnya : flavon, apigenin, dan luteolin), flavonols (contohnya : quercetin, kaemprefol, myricetin dan fisetin), flavanones (contohnya : flavanone, hesperetin, dan naringenin), dan lainnya. Flavanoid memiliki kemampuan biologi yang luas dalam menjaga kesehatan manusia dan membantu mengurangi resiko berbagai penyakit. Salah satu fungsi senyawa flavanoid di dalam tubuh adalah sebagai anti hipertensi. Beberapa penelitian terakhir telah terfokus pada efek kardiovaskuler protektif dari quercetin. Khususnya, efek anti hipertensi dari senyawa flavonols. Quercetin, kaempfrenol, dan myricetin merupakan tiga kelompok flavonol yang

\footnotetext{
Asep Badrujamaludin*, Budiman ${ }^{2}$, Tifany Desty Erisandi ${ }^{3}$

'Program Studi Keperawatan (D3), STIKES Jenderal Achmad Yani- Cimahi. *Email: dru.stikesr@gmail.com

${ }^{2}$ Program Studi llmu Kesehatan Masyarakat (SI), STIKES Jenderal Achmad Yani- Cimahi

${ }^{3}$ Program Studi llmu Keperawatan Si, STIKES Jenderal Achmad Yani- Cimahi
} 
Perbedaan air rebusan daun seledri dan air rebusan daun salam terhadap penurunan tekanan darah pada pra lansia dengan hipertensi primer

sering muncul pada makanan kita. Kemampuan

Flavonol bertindak sebagai antioksidan utama pada sistem biologi. Pemberian suplemen quercetin $730 \mathrm{mg} / \mathrm{hr}$ selama 28 hari terbukti efektif dalam menurunkan tekanan darah pada pasien hipertensi (Belasuriya \& Rupasinghe, 2011).

Sehingga dapat disimpulkan bahwa flavonoid dapat menghambat ACE. Diketahui ACE memegang peran dalam pembentukan angiotensi Il yang merupakan salah satu penyebab hipertensi. Angiotensi II menyebabkan pembuluh darah menyempit, yang dapat menaikkan tekanan darah. ACE inhibitor menyebabkan pembuluh darah melebar sehingga darah lebih banyak mengalir ke jantung, mengakibatkan penurunan darah.
ACE inhibitor dari flavonol telah banyak dilaporkan.

Selain itu, penggunaan daun salam dapat menurunkan darah karena efak diuretik yaitu flavonoid. Memobilisasi cairan edema, mengubah keseimbangan cairan ekstrasel dan sehingga tekanan darah normal merupakan fungsi utama diuretik. Natrium yang ada di dalam intraseluler darah menuju ekstraseluler memasuki tubulus ginjal merupakan hasil dari flavonoid yang berfungsi seperti kalium dengan mengabsorpsi ion ion elektrolit sehingga Glomerular filtration rate (GFR) ginjal mampu mengeluarkan produk buangan dari tubuh dengan baik dan lebih cepat (Nadila, 2014).

Tabel 3. Analisis Perbedaan Rerata Tekanan Darah Rerata Setelah Diberikan Intervensi

\begin{tabular}{|c|c|c|c|c|c|c|}
\hline Variable & Kelompok & & Mean & SD & $p$-value & $\mathbf{N}$ \\
\hline \multirow[t]{2}{*}{$\begin{array}{l}\text { Tekanan Darah Sistolik } \\
\text { Setelah Intervensi }\end{array}$} & $\begin{array}{l}\text { Intervensi } \\
\text { Rebusan } \\
\text { Seledri ) }\end{array}$ & $\begin{array}{l}1 \text { (Air } \\
\text { Daun }\end{array}$ & 140,36 & 5,954 & & 11 \\
\hline & $\begin{array}{l}\text { Intervensi } \\
\text { Rebusan } \\
\text { Salam) }\end{array}$ & 2 (Air & 137,27 & 9,318 & 0,365 & 11 \\
\hline \multirow[t]{2}{*}{$\begin{array}{l}\text { Tekanan Darah Diastolik } \\
\text { Setelah Intervensi }\end{array}$} & $\begin{array}{l}\text { Intervensi } \\
\text { Rebusan } \\
\text { Seledri) }\end{array}$ & $\begin{array}{r}1 \text { (Air } \\
\text { Daun }\end{array}$ & 84,82 & 5,056 & 0,574 & 11 \\
\hline & $\begin{array}{l}\text { Intervensi } \\
\text { Rebusan } \\
\text { Salam) }\end{array}$ & 2 (Air & 86,27 & 6,769 & & 11 \\
\hline
\end{tabular}

Berdasarkan hasil penelitian pada tabel 5 didapatkan rerata tekanan darah sistolik sesudah pemberian air rebusan daun seledri dan air rebusan daun salam adalah $140,36 \mathrm{mmHg}$ dan $137,27 \mathrm{mmHg}$. Hasil uji $t$ independent didapatkan $p$ value $0,365>0,05$. Pada tekanan darah diastolik didapatkan rerata tekanan darah diastolik sesudah pemberian air rebusan daun seledri dan air rebusan daun salam adalah $84,82 \mathrm{mmHg}$ dan $86,27 \mathrm{mmHg}$. Hasil uji T-independent didapatkan $p$ value $0,574>0,05$, dari keterangan tersebut, dapat disimpulkan bahwa tidak terdapat perbedaan yang signifikan efektivitas air rebusan daun seledri dan air rebusan daun salam terhadap penurunan tekanan darah pada pra lansia dengan hipertensi.

Penurunan tekanan darah yang dialami responden setelah diberikan air rebusan daun seledri dibuktikan oleh hasil penelitian yang dilakukan oleh Sakinah \& Ashari. (2018) tentang adanya pengaruh pemberian air rebusan daun seledri. Didapatkan hasil rerata tekanan darah sistolik dan diastolik sebelum diberikan air rebusan daun seledri diperoleh rata-rata (mean) 148,67 mmHg dan $95,33 \mathrm{mmHg}$. Sedangkan hasil rerata tekanan darah sistolik dan diastolik setelah diberikan air rebusan daun seledri adalah $139,33 \mathrm{mmHg}$ dan $90,33 \mathrm{mmHg}$ dengan selisih rerata tekanan darah sistolik $9,34 \mathrm{mmHg}$ dan diastolik $5,00 \mathrm{mmHg}$. Sehingga dapat disimpulkan terjadinya penurunan tekanan darah sebelum dan sesudah diberikan air rebusan daun seledri dilihat dari mekanisme umum

\footnotetext{
Asep Badrujamaludin ${ }^{1 *}$, Budiman ${ }^{2}$, Tifany Desty Erisandi ${ }^{3}$

'Program Studi Keperawatan (D3), STIKES Jenderal Achmad Yani- Cimahi. *Email: dru.stikesr@gmail.com

${ }^{2}$ Program Studi llmu Kesehatan Masyarakat (SI), STIKES Jenderal Achmad Yani- Cimahi

${ }^{3}$ Program Studi llmu Keperawatan SI, STIKES Jenderal Achmad Yani- Cimahi
} 
seledri dalam mengontrol tekanan darah antara lain, memberikan efek dilatasi pada pembuluh darah dan menghambat angiotensi converting enzym (ACE). Sedangkan penurunan tekanan darah yang dialami responden setelah mengonsumsi air rebusan daun salam dibuktikan dengan adanya penelitian Dafriani. (2016) didapatkan hasil pengukuran tekanan darah sistol pada kelompok intervensi sebelum diberikan air rebusan daun salam diperoleh rata-rata (mean) yaitu $161 \mathrm{mmHg}$ dan kelompok kontrol $154 \mathrm{mmHg}$. Hasil pengukuran tekanan darah sistol setelah diberikan perlakuan selama 5 hari pada kelompok intervensi diperoleh rata-rata (mean) yaitu 121 $\mathrm{mmHg}$ dan pada kelompok kontrol $155 \mathrm{mmHg}$. Pengukuran tekanan darah diastolik pada kelompok intervensi sebelum diberikan air rebusan daun salam diperoleh rata-rata (mean) yaitu 96 $\mathrm{mmHg}$ dan pada kelompok kontrol $95 \mathrm{mmHg}$. Hasil pengukuran tekanan diastol setelah diberikan perlakuan pada kelompok intervensi diperoleh ratarata (mean) $76 \mathrm{mmHg}$ dan pada kelompok kontrol $92 \mathrm{mmHg}$. Selisih rerata tekanan darah sistolik dan diastolik yang didapatkan pada kelompok intervensi $40 \mathrm{mmHg}$ dan $20 \mathrm{mmHg}$, sedangkan pada kelompok kontrol $-1 \mathrm{mmHg}$ dan $3 \mathrm{mmHg}$. Terjadinya perbedaan tekanan darah sebelum dan sesudah diberikan air rebusan daun salam disebabkan daun salam mengandung senyawa flavonoid yang berpengaruh sebagai vasodilator pembuluh darah.

Daun Seledri dan Daun salam memiliki kandungan senyawa aktif seperti flavonoid. Flavanoid adalah suatu senyawa yag diperlukan untuk mempertahankan relaksasi pembuluh darah (vasodilatasi) dan juga sebagai inhibitor angiotensi converting enzym (ACE) dengan menghambat aktivitas ACE maka pembentukkan angiotensi II dapat dibatasi sehingga dapat mencegah hipertensi (Yulianti, Rahayu, \& Mega, 2014). Dari penjelasan tersebut dapat disimpulkan bahwa terapi air rebusan daun seledri dan daun salam dapat membantu mengurangi atau mengontrol tekanan darah pada pra lansia dengan hipertensi.

\section{SIMPULAN}

Berdasarkan hasil penelitian, pengolahan data, dan pembahasan mengenai "Perbedaan Air Rebusan Daun Seledri Dan Air Rebusan Daun Salam Terhadap Penurunan Tekanan Darah Pada Pra Lansia Dengan Hipertensi Primer Di Wilayah Kerja Puskesmas Cigugur Tengah", maka dapat diambil kesimpulan sebagai berikut : Nilai rata-rata tekanan darah sistolik pada pra lansia dengan hipertensi sebelum diberikan intervensi 1 dengan pemberian air rebusan daun seledri yaitu 151,18 $\mathrm{mmHg}$ dan rata-rata tekanan darah diastolik yaitu $94,82 \mathrm{mmHg}$. Sedangkan sesudah diberikan intervensi 1 rata-rata tekanan darah sistolik yaitu $140,36 \mathrm{mmHg}$ dan rata-rata tekanan darah diastolik yaitu $84,82 \mathrm{mmHg}$.Nilai rata-rata tekanan darah sistolik pada pra lansia dengan hipertensi sebelum diberikan intervensi 2 dengan pemberian air rebusan daun salam yaitu $151,18 \mathrm{mmHg}$ dan rata-rata tekanan darah diastolik yaitu 98,18 $\mathrm{mmHg}$. Sedangkan sesudah diberikan intervensi 2 rata-rata tekanan sistolik yaitu $137,27 \mathrm{mmHg}$ dan rata-rata tekanan darah diastolik yaitu 86,27 $\mathrm{mmHg}$.

Ada perbedaan rerata tekanan darah sistolik dan diastolik sebelum dan sesudah pada kelompok air rebusan daun seledri dengan $p$ value sistolik 0,001 dan diastolik 0,001 ( $p$ value $\leq 0,05$ ).Ada perbedaan rerata tekanan darah sistolik dan diastolik sebelum dan sesudah pada kelompok air rebusan daun salam dengan $p$ value sistolik 0,001 dan diastolik 0,001 ( $p$ value $\leq 0,05$ ). Tidak terdapat perbedaan rata-rata tekanan darah pada pra lansia dengan hipertensi sesudah diberikan intervensi 1 dengan pemberian air rebusan daun seledri dan intervensi 2 dengan pemberian air rebusan daun salam dari hasil uji statistik T-test Independent didapatkan nilai ( $p$ value) tekanan darah sistolik $0,365>$ a $(0,05)$ dan tekanan darah diastolik 0,574 $>a(0,05)$.

\section{SARAN}

Hasil penelitian ini diharapkan dapat dijadikan bahan acuan bagi pra lansia dengan Hipertensi dalam memanfaatkan air rebusan daun seledri dan air rebusan daun salam sebagai terapi antihipertensi dan dapat dikonsumsi secara rutin agar mendapatkan hasil yang maksimal agar tidak bergantung pada terapi farmakologis. Diharapkan puskesmas dapat mensosialisasikan mengenai terapi komplementer antihipertensi salah satunya menggunakan air rebusan daun seledri dan air rebusan daun salam untuk menurunkan tekanan darah pada penderita hipertensi di wilayah kerja Puskesmas Cigugur Tengah.

Hasil penelitian ini diharapan dapat dijadikan bahan acuan bagi keluarga dan masyarakat dalam memanfaatkan air rebusan daun seledri dan air rebusan daun salam sebagai terapi antihipertensi 
Perbedaan air rebusan daun seledri dan air rebusan daun salam terhadap penurunan tekanan darah pada pra lansia dengan hipertensi primer

dan dapat dikonsumsi secara rutin agar mendapatkan hasil yang maksimal agar tidak bergantung pada terapi farmakologis. Hasil penelitian ini diharapkan dapat dijadikan bahan referensi yang berkaitan dengan efektivitas air rebusan daun seledri dan air rebusan daun salam terhadap tekanan darah pada penderita hipertensi. Selain itu, penelitian selanjutnya juga diharapkan untuk mempertimbangkan faktor lain yang dapat mempengaruhi tekanan darah seperti tingkat stress dan asupan makanan yang dikonsumsi responden saat intervensi diberikan.

\section{DAFTAR PUSTAKA}

Andria, K. M. (2013). Hubungan antara perilaku olahraga, stress dan pola makan dengan tingkat hipertensi pada lanjut usia di posyandu lansia Kelurahan Gebang Putih Kecamatan Sukolilo Kota Surabaya. Jurnal Promkes, 1(2), 111-117.

Asmawati, N., Purwati, P., \& Handayani, R. S. (2016). Efektivitas Rebusan Seledri dalam Menurunkan Tekanan Darah pada Lansia Penderita Hipertensi di Posyandu Lansia Kelurahan Pajar Bulan Kecamatan Way Tenong Lampung Barat. Jurnal Kesehatan, 6(2).

Aspiani, R. Y. (2010). Buku ajar asuhan keperawatan klien gangguan kardiovaskular: aplikasi NIC \& NOC. EGC.

Balasuriya, B. N., \& Rupasinghe, H. V. (2011). Plant flavonoids as angiotensin converting enzyme inhibitors in regulation of hypertension. Functional Foods in Health and Disease, 1(5), 172-188.

Dinas Kesehatan Kota Cimahi.(2018). Profil Dinas Kesehatan Kota Cimahi. Cimahi : Dinkes Kota Cimahi

Dinas Kesehatan Provinsi Jawa Barat. (2016, November 12). Profil Kesehatan Tahun 2015. Retrivied Februari 10, 2019, from Dinas Kesehatan Jawa Barat: http://www.diskes.jabarprov.go.id/index.php/arsip/ categories/MTEz/profile-kesehatan

Herliana, E. (2013). Penyakit Asam Urat Kandas Berkat Herbal. Cetakan pertama, $h, 32$.
Junaedi, E. S. P., Yulianti, I. S., \& Rinata, M. G. (2013). Hipertensi kandas berkat herbal. FMedia.

Morika, H. D., \& Yurnike, M. W. (2016). Hubungan Terapi Farmakologi Dan Konsumsi Garam Dalam Pencapaian Target Tekanan Darah Pada Lansia Penderita Hipertensi Di Puskesmas Lubuk Buaya Padang. Jurnal Kesehatan Medika Saintika, 7(2).

Muzakar, N. (2012). Pengaruh pemberian air rebusan daun seledri terhadap penurunan tekanan darah penderita hipertensi. Jurnal Pembangunan Manusia, 6(1).

Nadila, F. (2014). Antihypertensive potential of chayote fruit extract for hypertension treatment. Jurnal majority, 3(7).

Putri, A. P. (2015). Pengaruh pemberian ekstrak daun salam (syzygium polyanthum) terhadap pertumbuhanbakteri bacillus cereus (Doctoral dissertation, UNIMED).

Sakinah, S., \& Ashari, H. K. (2018). Pengaruh rebusan daun seledri terhadap penurunan tekanan darah pada pasien hipertensi di wilayah kerja puskesmas Pangkajene Kabupaten Sidrap. Jurnal IImiah Kesehatan Diagnosis, 12(3), 261-266.

Saputra, O., \& Fitria, T. (2016). Khasiat Daun Seledri (Apium graveolens) Terhadap Tekanan Darah Tinggi Pada Pasien Hiperkolestrolemia. Jurnal Majority, 5(2), 120-125.

Triyanto, E. (2014). Pelayanan keperawatan bagi penderita hipertensi secara terpadu. Yogyakarta: Graha IImu.

Widiasari, S. (2018). Mekanisme Inhibisi Angiotensin Converting Enzym oleh Flavonoid pada Hipertensi. Collaborative Medical Journal (CMJ), 1(2), 30-44.

Wijayakesuma, H. (2015). Ramuan tradisional untuk pengobatan darah tinggi. Niaga Swadaya.

\footnotetext{
Asep Badrujamaludin ${ }^{1 *}$, Budiman ${ }^{2}$, Tifany Desty Erisandi ${ }^{3}$

'Program Studi Keperawatan (D3), STIKES Jenderal Achmad Yani- Cimahi. *Email: dru.stikesr@gmail.com

${ }^{2}$ Program Studi llmu Kesehatan Masyarakat (SI), STIKES Jenderal Achmad Yani- Cimahi

${ }^{3}$ Program Studi llmu Keperawatan SI, STIKES Jenderal Achmad Yani- Cimahi
} 